\title{
PENGARUH PEMBERIAN BEBERAPA JENIS MIKORIZA (Glomus Sp) TERHADAP PERTUMBUHAN DAN HASIL TANAMAN KEDELAI (Glycine max (L.) Merill.)
}

DI POLYBAG

\author{
Gandhi Ihza Fadli *, Rainiyati dan Mukhsin \\ Jurusan Agroekoteknologi Fakultas Pertanian, Universitas Jambi \\ Jl. Raya Jambi - Ma. Bulian KM.15 Mendalo Darat, 36136 \\ gandhiihzafadli@gmail.com (*Penulis untuk korespondensi)
}

\begin{abstract}
ABSTRAK
Penelitian ini bertujuan untuk mempelajari pengaruh beberapa jenis mikoriza terhadap pertumbuhan dan hasil tanaman kedelai di polybag dan untuk mendapatkan jenis mikoriza yang terbaik untuk pertumbuhan dan hasil tanaman kedelai di polybag. Penelitian ini dilaksanakan di Laboratorium dan Teaching and Research Farm Fakultas Pertanian Universitas Jambi, Desa Mendalo Indah, Kecamatan Jambi Luar Kota, Muaro Jambi selama 4 bulan yaitu dari 26 Agustus sampai dengan bulan 28 Desember 2017. Perlakuan yang di uji yaitu Glomus sp1, Glomus sp2, Glomus sp3, Glomus sp4, Glomus sp5, dan gabungan Glomus sp1 sampai sp5 dengan pemberian dosis sebanyak 20 g per tanaman dan disusun menggunakan Rancangan Acak Lengkap (RAL) satu faktor dengan empat ulangan. Hasil penelitian menunjukkan bahwa terdapat pengaruh jenis Mikoriza (Glomus sp) terhadap beberapa parameter pengamatan, yaitu pada parameter jumlah polong pertanaman dan jumlah polong berisi pertanaman, pada parameter bobot tajuk, bobot akar, bobot 100 biji, hasil per tanaman, infeksi akar dan serapan P tanaman belum ditemukan pengaruh yang signifikan pada tanaman kedelai. Pemberian jenis Glomus sp2 dan Glomus sp3 memberikan pengaruh terbaik pada pertumbuhan tanaman kedelai.
\end{abstract}

Kata kunci : Kedelai, Mikoriza, Arbuskular, dan Glomus sp

\section{PENDAHULUAN}

Kedelai (Glicine max. (L.) Merril), merupakan komoditi pangan utama setelah padi dan jagung, tergolong tanaman kacang- kacangan yang merupakan sumber protein yang cukup tinggi. Kedelai memiliki kandungan kadar protein sekitar 30-40\% (Nugraha et al., 2000). Produksi kedelai di Provinsi Jambi tahun 2015 sebesar 6.732 ton biji kering, dengan luas panen seluas 4.906 ha, dan produktivitas sebesar 13,72 ku/ha. Dalam hal ini produksi kedelai mengalami penurunan sebesar 68 ton biji kering atau setara 0,99\% dibanding dengan tahun 2014 yang memperoleh hasil produksi sebesar 6.800 ton biji kering (Badan Pusat Statistik Provinsi Jambi, 2016). Dengan luas lahan tersebut tanah ultisol sangat berpotensi untuk dikembangkan sebagai lahan produktif untuk tanaman pertanian, namun untuk pemanfaatannya ultisol mengalami beberapa kendala seperti sifat fisik, kimia dan biologi. 
Tanah ultisol memiliki struktur tanah yang kurang baik, $\mathrm{pH}$ yang rendah, kandungan $\mathrm{Al}$ dan $\mathrm{Fe}$ yang tinggi serta rendahnya unsur hara makro $(\mathrm{N}, \mathrm{P}, \mathrm{K})$ dalam tanah. Khusus unsur P tidak tersedianya dalam tanah masam akibat fiksasi Fosfat ionion $\mathrm{Al}$ dan $\mathrm{Fe}$ membentuk $\mathrm{Al} / \mathrm{P}$ dan $\mathrm{Fe} / \mathrm{P}$, sehingga tidak tersedia bagi tanaman (Kartika et al. 2015).

Salah satu upaya yang dapat dilakukan untuk mengeksplorasi unsur $\mathrm{P}$ dengan memanfaatkan mikroorganisme yang bermanfaat salah satunya adalah cendawan Mikoriza. Penggunaan cendawan mikoriza sangat aman dipakai dan tidak menyebabkan pencemaran lingkungan. Bila mikoriza tertentu telah berkembang dengan baik di suatu tanah, maka manfaatnya akan diperoleh untuk selamanya. Mikoriza juga membantu tanaman untuk beradaptasi pada $\mathrm{pH}$ rendah. Demikian pula vigor tanaman bermikoriza yang baru dipindahkan ke lapang lebih baik dari yang tanpa mikoriza (Anas, 1997).

Fungi mikoriza adalah suatu cendawan yang bersimbiosis secara mutualisme dengan akar tanaman yang memiliki peranan penting dalam siklus hara dan ekosistem. Simbiosis ini terjadi saling menguntungkan, fungi memperoleh karbohidrat dan unsur pertumbuhan lain dari tanaman inang, sebaliknya fungi memberi keuntungan kepada tanaman inang, dengan cara membantu tanaman dalam menyerap unsur hara terutama unsur fosfor (Pulungan, 2013).

Bakhtiar, Suhartini, dan Djamaan (2005) menyatakan bahwa tanaman yang diinokulasi dengan Fungi Mikoriza Arbuskula (FMA) memiliki perbedaan respon pertumbuhan dengan tanaman yang tidak diinokulasi. Pertumbuhan tanaman memerlukan unsur hara dan air, salah satu unsur yang terpenting adalah P. Tanaman yang diinokulasi dengan FMA mampu meningkatkan pertumbuhan tanaman. Hal ini diduga karena adanya peningkatan penyerapan $\mathrm{P}$ akibat meningkatnya aktivitas FMA. Fungi mikoriza arbuskula termasuk kelompok fungi endomikoriza, membentuk vesikular dan arbuskular yang besar di dalam sel korteks dapat dijumpai pada jenis Glomus (Dewi, 2007). Menurut Brundrett (2008) dan Nusantara, dkk., (2012) ciri-ciri Glomus yaitu hifa memiliki percabangan, ada klamidospora, Percabangan hifa kadang berbentuk tipe $\mathrm{H}$, vesikel berbentuk lonjong, terdapat arbuscular dan warna spora putih, kuning dan coklat. Hasil dari beberapa penelitian FMA menunjukkan bahwa pertumbuhan Glomus memiliki tingkat adaptasi yang tinggi terhadap kondisi lingkungan esktrim (Sayuti,et al. 2011). Glomus mampu hidup pada kondisi tanah asam (Puspitasari, et al. 2012) dan kondisi tanah netral (Sundari, et al. 2011), sehingga Glomus paling banyak dijumpai bersimbiosis dengan akar berbagai jenis tanaman (Navarro et al. 2012). 


\section{BAHAN DAN METODE}

Penelitian ini dilaksanakan di Laboratorium dan Teaching and Research Farm Fakultas Pertanian Universitas Jambi, Desa Mendalo Darat, Kecamatan Jambi Luar Kota. Kabupaten Muaro Jambi dengan ketinggian tempat $\pm 35 \mathrm{~m}$ dpl. Penelitian ini dilaksanakan selama 4 bulan, dimulai bulan September sampai bulan Desember 2017.Bahan yang digunakan pada dengan analisis ragam, kemudian dilanjutkan dengan uji Beda Nyata Terkecil (BNT) pada taraf $\alpha=5 \%$.

Penelitian ini menggunakan inokulan mikoriza yang didapat dari perbanyakan secara dikulturkan pada inang tanaman Pueraria javanica (PJ) sebanyak 20 g per tanaman, benih kedelai Varietas Anjasmoro, polybag ukuran 35 x $40 \mathrm{~cm}$, tanah ultisol yang sudah disterilkan, pupuk kandang ayam sebagai pupuk dasar dengan dosis $1: 1 / 2,10 \% \mathrm{KOH}, 3 \% \mathrm{H} 2 \mathrm{O} 2,1 \% \mathrm{HCL}$, Lactaglycerol Solution, Trypan blue $0,05 \%$, aluminium foil, tali raffia, dan label. Alat yang digunakan dalam penelitian ini adalah cangkul, ayakan tanah, mikroskop stereo, mikroskop compound, pinset, timbangan analitik, petridish, beaker glass, centrifuges, pinset, ajir, gembor, dan alat tulis.

Penelitian ini dilakukan dengan menggunakan Rancangan Acak Lengkap (RAL) dengan satu factor yaitu pemberian Mikoriza (M) dengan 6 jenis perlakuan yaitu Glomus sp1, Glomus sp2, Glomus sp3, Glomus sp4, Glomus sp5, dan Gabungan Glomus sp 1 sampai Glomus sp 5. Variabel yang diamati adalah bobot tajuk, bobot kering akar, jumlah polong per tanaman, jumlah polong berisi per tanaman, bobot 100 biji, hasil pertanaman, infeksi akar, dan serapan $\mathrm{P}$ tanaman. Untuk melihat pengaruh perlakuan atau hasil pengamatan, dianalisis dengan analisis ragam, kemudian dilanjutkan dengan uji Beda Nyata Terkecil (BNT) pada taraf $\alpha=5 \%$.

\section{HASIL DAN PEMBAHASAN}

\section{Bobot tajuk dan bobot akar}

Hasil sidik menunjukkan perlakuan pemberian berbagai jenis Glomus tidak berpengaruh nyata terhadap bobot tajuk dan bobot akar tanaman. 
Tabel 1. Bobot tajuk dan bobot akar tanaman menurut perlakuan jenis Glomus

\begin{tabular}{ccc}
\hline Jenis Glomus & $\frac{\text { Bobot Tajuk }}{(\mathrm{g})}$ & $\frac{\text { Bobot Akar }}{(\mathrm{g})}$ \\
\hline sp1 & 46,7 & 4,1 \\
sp2 & 61,5 & 5,6 \\
sp3 & 58 & 5 \\
sp4 & 49,8 & 4,9 \\
sp5 & 49,9 & 4,3 \\
sp1 sampai sp 5 & 54,1 & 5 \\
\hline
\end{tabular}

\section{Jumlah polong berisi per tanaman}

Hasil sidik ragam menunjukan perlakuan pemberian berbagai jenis Glomus berpengaruh nyata terhadap jumlah polong berisi tanaman.

Tabel 3. Jumlah polong berisi menurut perlakuan jenis Glomus

\begin{tabular}{cc}
\hline Jenis Glomus & $\begin{array}{c}\text { Jumlah Polong Berisi } \\
\text { (polong) }\end{array}$ \\
\hline sp1 & 58 \\
sp2 & 104,6 \\
sp3 & 102,4 \\
sp4 & 63,7 \\
sp5 & 61,6 \\
sp1 sampai sp5 & 5,7 \\
\hline
\end{tabular}

\section{Bobot 100 biji}

Hasil sidik ragam menunjukkan perlakuan pemberian berbagai jenis Glomus tidak pengaruh nyata terhadap berat 100 biji tanaman.

Tabel 4. Bobot 100 biji tanaman menurut perlakuan Jenis Glomus

\begin{tabular}{cc}
\hline Jenis Glomus & Bobot 100 biji $(\mathrm{g})$ \\
\hline sp1 & 9,2 \\
sp2 & 12,7 \\
sp3 & 13,3 \\
sp4 & 9,9 \\
sp5 & 10,8 \\
sp1 sampai sp5 & 11,3 \\
\hline
\end{tabular}




\section{Hasil per tanaman}

Hasil sidik ragam menunjukkan perlakuan pemberian jenis Glomus tidak berpengaruh nyata terhadap berat hasil per tanaman.

\begin{tabular}{cc} 
Jenis Glomus & Hasil Per tanaman $(\mathrm{g})$ \\
\hline sp1 & 16,2 \\
sp2 & 29,1 \\
sp3 & 28 \\
sp4 & 17,8 \\
sp5 & 17,3 \\
sp1 sampai sp5 & 21,1 \\
\hline
\end{tabular}

\section{Infeksi akar}

Hasil sidik ragam menunjukkan perlakuan pemberian berbagai jenis Glomus berpengaruh nyata terhadap persentase infeksi akar tanaman kedelai.

Tabel 6. Persentase infeksi akar menurut perlakuan jenis Glomus

\begin{tabular}{cc}
\hline Jenis Glomus & Infeksi Akar (\%) \\
\hline sp1 & 72,5 \\
sp2 & 87,5 \\
sp3 & 79,2 \\
sp4 & 72,5 \\
sp5 & 80 \\
sp1 sampai sp5 & $\underline{85}$ \\
\hline
\end{tabular}

\section{Serapan $\mathbf{P}$ tanaman}

Hasil sidik ragam menunjukkan perlakuan pemberian berbagai jenis Glomus tidak pengaruh nyata terhadap serapan $\mathrm{P}$ tanaman.

Tabel 7. Persentase serapan P menurut perlakuan jenis Glomus

\begin{tabular}{cc}
\hline Jenis Glomus & $\begin{array}{c}\text { Serapan P Tanaman } \\
(\mathrm{g})\end{array}$ \\
\cline { 2 - 2 } sp1 & 25.48 \\
sp2 & 33.90 \\
sp3 & 29.02 \\
sp4 & 24.52 \\
sp5 & 24.87 \\
sp1 sampai sp5 & 24.87 \\
\hline
\end{tabular}




\section{PEMBAHASAN}

Inokulasi FMA pada umumnya memegang peranan yang penting dalam membantu pertumbuhan tanaman, sehingga dapat memberikan pengaruh positif bagi pertumbuhan tanaman. Hasil penelitian ini menunjukkan bahwa perlakuan berbagai jenis Glomus belum mampu meningkatkan bobot brangkas dan bobot kering akar, hal ini disebabkan karena tanaman yang terinfeksi FMA menyerap unsur hara yang cukup untuk pertumbuhan tanaman. Tanaman yang diinokulasi FMA tumbuh lebih subur karena luas permukaan akar yang lebih besar untuk menyerap hara dan jumlah daun yang lebih banyak untuk mendukung proses fotosintesis dan akan menghasilkan bahan kering yang lebih banyak (Muis et al., 2013).

Kemampuan setiap jenis FMA berbeda dalam meningkatkan pertumbuhan tanaman. Pemberian Glomus sp2 diduga memiliki luas permukaan akar yang lebih besar untuk menyerap hara dan jumlah daun yang lebih banyak untuk mendukung proses fotosintesis sehingga menghasilkan bahan kering yang lebih banyak. Menurut Anjarsary et al. (2007) nilai bobot kering tanaman yang tinggi menunjukkan terjadinya peningkatan proses fotosintesis karena unsur hara yang diperlukan cukup tersedia. Hal tersebut berhubungan dengan hasil fotosintat yang ditranslokasikan ke seluruh organ tanaman untuk pertumbuhan tanaman, sehingga memberikan pengaruh yang nyata pada biomassa tanaman.

Pemberian mikoriza memberikan pengaruh yang lebih baik terhadap pertumbuhan dan komponen produksi tanaman dibandingkan tanpa pemberian mikoriza (Nasution, et al., 2013). Terdapat tiga tahapan bagaimana pengaruh FMA terhadap ketersediaan dan penyerapan unsur hara. Pada tahap pertama, terjadi modifikasi kimia oleh FMA terhadap akar tanaman, sehingga tanaman mengeksudasi asam-asam organik dan enzim fosfatase asam yang memacu proses mineralisasi $\mathrm{P}$. Eksudasi akar terjadi sebagai respon tanaman terhadap kondisi tanah yang kahat $\mathrm{P}$, yang mempengaruhi kimia rizosfer (Marschner, 1995). Tahap selanjutnya, FMA memperpendek jarak difusi P ke permukaan akar. Difusi merupakan mekanisme utama bagi pergerakan P ke permukaan akar akibat perbedaan gradien konsentrasi dan berlangsung sangat lambat. Jarak difusi tersebut dapat diperpendek dengan adanya hifa eksternal FMA (Bolan, 1991). Terakhir, akar tanaman bermikoriza masih mampu menyerap hara $\mathrm{P}$ sekalipun konsentrasi ion fosfat berada di bawah konsentrasi minimum yang dapat diserap oleh akar (Bolan, 1991). Proses ini terjadi karena afinitas hifa eksternal yang lebih tinggi atau peningkatan daya tarik-menarik ion-ion fosfat yang menyebabkan pergerakan P lebih cepat ke dalam hifa FMA (Smith dan Read, 1997). Menurut (Same, 2011) Peningkatan serapan $\mathrm{P}$ oleh tanaman yang diinokulasi dengan cendawan mikoriza arbuskula sebagian besar karena hifa eksternal dari cendawan mikoriza arbuskula yang berperan sebagai sistem perakaran. Hal ini karena hifa eksternalnya menyediakan permukaan yang lebih efektif dalam menyerap unsur hara dari tanah yang kemudian dipindahkan ke akar inang.

Berdasarkan hasil penelitian jenis FMA glomus memberikan pengaruh terhadap jumlah polong per tanaman dan jumlah polong berisi per tanaman pada perlakuan Glomus sp2 memiliki nilai rata- rata tertinggi, hal ini disebabkan karena Glomus sp2 lebih cepat dalam menginfeksi akar, semakin banyak akar yang terinfeksi menyebabkan hifa yang terdapat diakar menyerap unsur hara lebih banyak sehingga tanaman mampu menyerap unsur hara yang dapat membantu tanaman dalam 
pembentukan polong. Sedangkan pada variabel bobot 100 biji dan hasil per tanaman, pemberian berbagai jenis FMA memberikan pengaruh yang sama pada bobot biji tanaman, dikarenakan FMA belum mampu meningkatkan ukuran biji pada tanaman kedelai sehingga bobot yang dihasilkan tidak jauh berbeda pada setiap perlakuan.

Perkembangan dan keberadaan FMA pada suatu tanaman ditunjukkan dengan nilai presentase infeksi pada akar atau jumlah kolonisasi pada akar tanaman. Berdasarkan hasil penelitian dalam persentase infeksi akar, infeksi FMA dengan perlakuan berbagai spesies glomus tergolong dalam kelas tinggi hinga sangat tinggi, sesuai dengan pendapat (Setiadi et al., 1992) kriteria kolonisasi akar 51-75 \% menunjukkan kriteria infeksi tinggi dan 76- $100 \%$ menunjukkan kriteria infeksi sangat tinggi. Perlakuan jenis mikoriza Glomus sp2 memiliki nilai rata-rata tertinggi, ini menunjukkan semakin besar infeksi FMA pada akar, maka keefektifitasannya dalam penyerapan unsur hara bagi pertumbuhan tanaman akan semakin meningkat (Hidayat 2003).

Smith dan Read (1997) menambahkan, FMA dicirikan dengan adanya vesikula dan arbuskula. Kedua struktur ini sangat berperan dalam hidup FMA. Arbuskula memiliki peranan penting karena fungsinya sebagai tempat pertukaran metabolit antara tanaman dan fungi. Adanya arbuskula sangat penting untuk mengidentifikasi bahwa telah terjadi infeksi pada akar tanaman (Delvian, 2005). Fungsi struktur vesikula adalah sebagai organ reproduktif atau organ penyimpanan makanan yang selanjutnya diangkut ke sel tempat pencernaan. Saat tanaman tua atau akan mati jumlah vesikel dijumpai akan meningkat. Vesikula dibentuk oleh hifa intraseluler atau interseluler dan dijumpai dalam sel korteks luar.

Selain meningkatkan pertumbuhan dan hasil tanaman, FMA juga meningkatkan daya serapan P (Kabirun, 2002). Penyerapan unsur hara khususnya P sangat dipengaruhi oleh panjang total hifa yang hidup, penyebaran hifa di dalam tanah dan oleh energi kenetik penyebaran hifa (Hapsoh 2003). Berdasarkan hasil penelitian pemberian beberapa spesies glomus pada tanaman kedelai memberikan daya serapan $\mathrm{P}$ yang baik untuk menunjang penyerapan unsur hara yang dibutuhkan untuk pertumbuhan tanaman. Pada perlakuan Glomus sp2 dan Glomus sp3 memiliki daya serapan P yang tinggi, terpenuhinya unsur hara $\mathrm{P}$ akan menunjang pertumbuhan tanaman.

Berdasarkan hasil penelitian ini secara keseluruhan pemberian FMA Glomus sp2 dapat meningkatkan jumlah polong per tanaman dan jumlah polong berisi per tanaman, hal ini diduga karena Glomus sp2 memiliki ukuran spora yang lebih besar daripada jenis Glomus lainnya. Ukuran spora yang besar dapat mempercepat terjadinya proses penetrasi kedalam akar. Menurut (Sylvia dan Jarstfer, 1994) bentuk propagul (spora dan hifa eksternal) mempengaruhi peningkatan presentase kolonisasi akar. Semakin besar infeksi/ kolonisasi pada akar, maka keefektifannya dalam penyerapan unsur hara bagi pertumbuhan tanaman akan semakin meningkat. Sedangkan pemberiaan FMA Glomus sp1-5 belum mampu meningkatkan pertumbuhan dan hasil tanaman, serta belum mampu meningkatkan infeksi akar dan serapan $\mathrm{P}$ tanaman, hal ini diduga karena gabungan spora menyebabkan terjadinya kompetisi antar spesies FMA dalam kolonisasi akar yang disebut sebagai faktor biotik, sehingga memiliki respon lambat dalam menginfeksi akar, selain itu juga setiap jenis FMA mempunyai kemampuan yang berbeda dalam meningkatkan serapan P. Hal tersebut didukung oleh (Anas dan Santosa, 1993) mengatakan perbedaan dalam meningkatkan serapan P dapat terjadi karena adanya perbedaan gerakan $\mathrm{P}$ dalam hifa sehingga menyebabkan terjadinya perbedaan 
efisiensi antara jenis FMA dalam meningkatkan pertumbuhan tanaman.

\section{KESIMPULAN}

1. Pemberian Glomus sp2 dan Glomus sp3 mampu meningkatkan jumlah polong per tanaman, jumlah polong berisi per tanaman, dan hasil per tanaman.

2. Pemberian Glomus sp2 dan Glomus sp3 merupakan perlakuan yang mampu memberikan pertumbuhan dan hasil terbaik.

\section{DAFTAR PUSTAKA}

Anas. 1997. Bioteknologi Tanah. Laboratorium Biologi Tanah. Jurusan Tanah. Fakultas Pertanian. IPB

Anas \& Santosa DA. 1993. Mikoriza Vesikular Arbuskular. Fakultas Pertanian IPB. Bogor.

Anjarsary, I. R. D., Rosniawati, S. dan Ariyanti, M. 2007. Pengaruh Kombinasi Pupuk P dan Kompos terhadap Pertumbuhan Tanaman Teh (Camellia Sinensis (L.) O. Kuntze) Belum Menghasilkan Klon Gambung

7. Laporan Penelitian Peneliti Muda UNPAD. PPTK Gambung.

Badan Pusat Statistik. 2016. Jambi Brundrett, M., N Bougher, B Dell, T Ggrove and N Malajemuk. 2008. Working wit mycorrhizes in forestry and agriculture Monograph. ACIAR. 32:374.

Bolan, NS. 1991. A Critical Review on the Role of Mycorrhizal in the Uptake of Phosphorus by Plants. Plant soil 134:189-209.

Dinas Pertanian Tanaman Pangan. 2007. Laporan Tahunan. Dinas Pertanian Tanaman Pangan Provinsi Jambi.

Dewi, I. R., 2007. Makalah Peran, Prospek dan Kendala dalam Pemanfaatan Endomikoriza. Jurusan Budidaya Pertanian Program Studi Agronomi FakultasPertanian. Universitas Padjadjaran.Jatinangor, Jawa Barat.

Delvian. 2005. Respon Pertumbuhan dan Perkembangan Cendawan Mikoriza Arbuskula dan Tanaman terhadap Salinitas Tanah. Fakultas Pertanian. Universitas Sumatera Utara. Medan.

Hapsoh. 2003. Kompatibilitas MVA dan Beberapa Genotipe Kedelai pada Berbagai Tingkat Cekaman Kekeringan Tanah Ultisol : Tanggap Morfofisiologi dan hasil. Disertasi.

Sekolah Pascasarjana Institut Pertanian Bogor.

Kartika, E., M.D. Duaja, dan Gusniwati (2016). Pertumbuhan Tanaman Kelapa Sawit Belum Menghasilkan (TBM I) pada Pemberian Mikoriza Indigen dan Dosis Pupuk Organik di Lahan Marjinal, Biospecies. Vol. 9 No.1, hal 29-37.

Kabirun, S. 2002. Tanggap padi gogo terhadap inokulasi mikoriza arbuskula danpemupukan fosfat di entisol. Jurnal Ilmu Tanah dan Lingkungan. 3 (2) : 49-56.

Manschner, H.1995. Mineral Nutrition of Higher Plant. Academic Press. London.

Muis, A., D. Indradewa, J. Widada. 2013. Pengaruh Inokulasi Mikoriza Arbuskular Terhadap Pertumbuhan dan Hasil Kedelai (Glycine Max (L.)Merrill) Pada Berbagai Interval Penyiram. Vegetalika 2(12):7-20.

Navarro, A. M., J. G. S. Moragues, A. V. Banuet, and M. Verdŭ, 2012. TheNetwork Structure of Plant-Arbuscular Mycorrhizal Fungi. NewPhytologist (2012) 194: 536547.

Nasution.T.H.et.al., 2013. Respon Pertumbuhan dan Produksi Kedelai ( Glycine Max (L) Merill) yang Diberi Mikoriza Arbuskular (FMA) Pada Tanah Salin. Jurnal Online Teknologiagro. Vol.2. No.1. 
Nusantara A, Y. Bertham, I. Mansur. 2012. Bekerja dengan Fungi Mikoriza Arbuskula. SEAMEO BIOTROP. Indonesia-Bogor.

Nugraha, U. S., D.S. Damardjati, dan S. Widowati. 2000. Pengembangan mutu kedelai untuk agroindustry, hal 27 - 38. Dalam L. W. Gunawan, N. Sunarlim, T. Handayani, B. Soegiharto, W. Adil, B. Priyanto, dan Suwarno (Eds.). Penelitian dan Pengembangan Produksi Kedelai di Indonesia. Pusat Penelitian dan Pengembangan Tanaman Pangan. Badan Penelitian dan Pengembangan Pertanian.

Puspitasari, D., K. I. Purwani, dan A. Muhibuddin, 2012. EksplorasiVesicular Arbuscular Mycorrhiza(VAM) Indigenousous pada LahanJagung di Desa Torjun, SampangMadura. Jurnal Sains dan Seni ITS Vol. 1, Hal. 19-22.

Sayuti, I., Zulfarina, E. R. Lubis. 2011. Identifikasi Jamur Mikoriza Arbuskula (JMA) Pada Tanah Gambut Bekas Terbakar Di Kota Pekanbaru Provinsi Riau. J. Pilar Sains 11 (1) 01-01:2011

Same. M. 2011. Serapan Phospat dan Pertumbuhan Bibit Kelapa Sawit Pada Tanah Ultisol Akibat Cendawan Mikoriza Arbuskula. Jurnal Penelitian Pertanian Terapan. Vol.11. (2): 69-76

Sundari, S., T. Nurhidayati, dan I, Trisnawati. 2011. Isolasi dan identifikasi mikoriza indigenousous dari perakaran tembakau sawah (Nicotianatabacum L) di area persawahan kabupaten Pamekasan Madura. (Skripsi) Jurusan Biologi, Fakultas Matematika dan Ilmu Pengetahuan Alam Institut Teknologi Sepuluh November. Surabaya.

Setiadi, Y. Mansur I, Budi SW dan Achmad 1992 Mikrobiologi Tanah Hutan. Petunjuk Laboratorium. Dirjen Pendidikan Tinggi. Pusat Antar Universitas Bioteknologi IPB. Bogor.

Smith S. E. \& Read D. S, 1997. Mycorrhizal Syimbiosis. Second Edition. Academic Press, Harcourt Brale and Company Publisher, London. 